\title{
РЕЦЕНЗІї
}

DOI https://doi.org/ 10.32845/2663-5666.2019.4.41

\author{
Мартин А.Г., \\ доктор економічних наук, доцент, \\ завідувач кафедри землевпорядного проектування \\ Національного університету біоресурсів і природокористування Украйни
}

\section{РЕЦЕНЗІЯ НА МОНОГРАФІЮ А.І. РІПЕНКА «ВИКОРИСТАННЯ ЗЕМЕЛЬ ДЛЯ МІСТОБУДІВНИХ ПОТРЕБ: ТЕОРЕТИЧНІ ТА ПРАКТИЧНІ ПРОБЛЕМИ» ${ }^{1}$}

Реформування земельних відносин на ринкових засадах, стрімкий розвиток містобудівної та інвестиційної діяльності в населених пунктах, необхідність забезпечення населення житлом і земельними ділянками для його будівництва з урахуванням вимог екологічної безпеки під час здійснення містобудівної діяльності, а також колосальне зростання економічного інтересу до земельних ділянок у містах із боку бізнесових кіл зумовлюють високий ступінь актуальності проведеного комплексного правового дослідження, його своєчасність для науки та нормотворчості.

Від того, як в Україні юридично, а також фінансово, організаційно, матеріально, технічно й архітектурно буде забезпечено використання інвестиційного потенціалу земель у межах населених пунктів, насамперед земель житлової та громадської забудови, безпосередньо залежить прогресивний соціально-економічний розвиток територій населених пунктів або ж відбуватимуться регресивні явища $з$ усіма негативними наслідками соціального, демографічного, економічного, культурологічного, духовного, юридичного та іншого характеру.

Недосконалість системи сучасного земельного та містобудівного законодавства України у сфері використання земель міських територій, відсутність необхідних нормативно-правових актів із питань правового регулювання використання земель для містобудівних потреб ускладнюють реалізацію на практиці земельно-правових норм щодо забезпечення сталого розвитку й функціонування населених пунктів країни, негативно впливають на стан правового забезпечення використання земель для містобудівних потреб, а також на додержання громадського порядку й безпеки, стабільність земельних відносин та інвестиційну привабливість міських земель. Саме тому зроблені автором науково-теоретичні та практичні висновки $є$ вагомим внеском у доробок сучасної науки як земельного, екологічного, так і цивільного та адміністративного права 3 урахуванням недостатнього рівня доктринального розроблення вказаної проблематики у вітчизняній

${ }^{1}$ Ріпенко А.І. Використання земель для містобудівних потреб: теоретичні та практичні проблеми : монографія. Одеса : ВД «Гельветика», 2019. 464 с. правовій науці.

Структуру монографії зумовили складність і багатогранність обраної теми. Робота має логічну побудову, що дало змогу всебічно дослідити основні теоретичні й практичні питання використання земель для містобудівних потреб у сучасних умовах. Вдало продумана структура розвідки дала можливість вичерпно розкрити проблематику обраної теми монографічної роботи. Автор починає дослідження iз загальнотеоретичних основ правового регулювання використання земель для містобудівних потреб (перший розділ). Розгляду правових засад використання земель, призначених для містобудівних потреб, присвячений другий розділ. У третьому розділі рецензованої монографії досліджено публічно-правові аспекти здійснення прав на землю для містобудівних потреб. У четвертому розділі монографічної роботи грунтовно й системно розглянуто приватноправові аспекти використання земельних ділянок у містобудуванні.

Безсумнівним здобутком автора є вдала спроба віднайти оптимальну модель регламентації відносин із використання земель для містобудівних потреб із застосуванням публічно-правового та приватноправового регулювання. Заслуговує на увагу позиція дослідника щодо того, що в сучасних умовах відмова від публічно-правової регламентації вказаних відносин або суттєве їх послаблення не є доцільними та можуть призвести до погіршення інвестиційного клімату в будівельній галузі.

Схвалення викликає твердження автора про необхідність здійснення невідкладної систематизації містобудівного законодавства України, оскільки містобудівельно-правові норми розосереджені за різними галузевими утвореннями. Водночас автор вважає передчасним сьогодні виділення містобудівного права як самостійної правової галузі в системі вітчизняного права, навіть незважаючи на наявність відносно сформованого предмета правового регулювання.

Суттєвим досягненням варто вважати висновок про запровадження в перспективі тривимірного кадастрового обліку та реєстрації земельних ділянок, що дасть можливість більш точно відображати просторові межі об'єктів кадастрового обліку.

Значний науковий інтерес викликає також підхід дослідника до вирішення проблемних правових 
питань стосовно поділу землі на категорії залежно від основного цільового призначення 3 огляду на сучасні тенденції розвитку територіального планування. Крім того, автор вважає за доцільне розпочати перехід до територіального планування з об'єднання відповідних кадастрів (земельного та містобудівних), поєднання планувальної документації, тобто усунення їі поділу на містобудівну й землевпорядну, злиття відповідних управлінських інституцій.

Викладене свідчить про те, що рецензована монографія А.І. Ріпенка є цілісним дослідженням сучасних теоретичних і практичних проблем використання земель для містобудівних потреб. На основі ретельного аналізу національного й зарубіжного законодавства в роботі вдалося розв'язати важливу наукову проблему, сформулювати нові теоретичні положення та запропонувати науково обгрунтовані висновки, розробити цінні практичні рекомендації щодо вдосконалення правового регулювання зазначених відносин. На безумовне схвалення заслуговує авторська пропозиція щодо внесення системних змін до Земельного кодексу України, Закону України «Про землеустрій», Закону України «Про охорону земель», Закону України «Про основи містобудування», Закону України «Про регулювання містобудівної діяльності», що може бути використана для вдосконалення сучасного вітчизняного земельного та містобудівного законодавства.

3 огляду на високу значущість порушеної тематики й широке коло досліджених питань можна дійти висновку, що монографія Ріпенка Артема Ігоровича «Використання земель для містобудівних потреб: теоретичні та практичні проблеми» $€$ завершеною самостійною та комплексною науковою працею, у якій розроблено науково-теоретичні й практичні засади подальшого формування механізму правового забезпечення використання земель для містобудівних потреб. Опублікована робота підготовлена на належному науково-теоретичному рівні та $є$ актуальною для вітчизняної правової науки. Вважаємо, що монографія А.І. Ріпенка буде цікавою та корисною для науковців і практичних працівників, студентів, а також широкого кола читачів, які цікавляться сучасними проблемами розвитку науки аграрного, земельного й екологічного права. 